\title{
An in-vitro model for the study of inhibin production by rat ovarian cells
}

\author{
France Croze* and P. Franchimont \\ Laboratoire de Radioimmunologie, Institut de Pathologie, C.H.U. Bât. B 23, Université de Liège, \\ Belgium
}

\begin{abstract}
Summary. A culture system for ovarian cells from immature rats injected with PMSG was developed to study the production of inhibin. The results showed that $2 \times 10^{6}$ cells per culture dish $(60 \times 15 \mathrm{~mm})$ were necessary for sustained production of inhibin and that serum was an obligatory component in the medium. Serum from bovine fetuses was better than serum from newborn calves for inhibin production. The constituents responsible for the maintenance of inhibin production by fetal bovine serum could be adsorbed with $1 \%$ charcoal and $0 \cdot 1 \%$ dextran.
\end{abstract}

\section{Introduction}

Much work has been done on the production and regulation of steroid secretion by ovarian cells in vitro (Channing, Tsai \& Sachs, 1976; Hillier, Knazek \& Ross, 1977; Orly, Sato \& Erickson, 1980; Hsueh, Welsh \& Jones, 1981). It is only recently, however, that attention has been given to the production of the proteinaceous inhibin-like substance by granulosa cells (Erickson \& Hsueh, 1978; Henderson \& Franchimont, 1981, 1983; Hermans, van Leeuwen, Debets, Sanders \& de Jong, 1982), but there has been little consideration of the effect of basal culture conditions on inhibin production.

The purpose of this study was (1) to determine the optimal culture conditions for ovarian cells obtained from immature rats injected with PMSG and (2) to measure detectable amounts of inhibin in the media so that a model for the study of the hormonal regulation of inhibin production could be proposed.

\section{Materials and Methods}

\section{Inhibin bioassay}

Inhibin activity was measured using an in-vitro bioassay with dispersed pituitary cells as described by Henderson \& Franchimont (1981). After the cells were allowed to attach for $48 \mathrm{~h}$, the culture medium was removed and the cells were exposed for 3-4 days to 150 or $300 \mu \mathrm{l}$ medium from cultured ovarian cells or to $0 \cdot 25,0.5,1.0$ or $2.0 \mathrm{U}$ of ovine inhibin reference standard derived from testicular lymph plasma (OTLP6; Eddie, Baker, Higginson \& Hudson, 1979) or rete testis fluid (RTFS: generous gift from Professor B. Hudson). The ovarian-cell culture media had been previously rotated at $4{ }^{\circ} \mathrm{C}$ for $16 \mathrm{~h}$ with $1.0 \%$ charcoal (Carbon Decolorizing Neutral Norit, Fisher Scientific Co., Fair Lawn, NJ, U.S.A.) and 0.1\% dextran (Dextran T 70, Pharmacia Fine Chemicals AB, Uppsala, Sweden) and then centrifuged and filtered on a $0.45 \mu \mathrm{m}$ cellulose millipore filter. The volume was adjusted to $1 \mathrm{ml}$ with Dulbecco's modification. of Eagle's medium

\footnotetext{
* Present address: Department of Physiology, Faculty of Medicine, University of Manitoba, Winnipeg, Manitoba, Canada R3E 0W3.
} 
supplemented with serum (DMEM $+\mathrm{S}$ ) as described by Henderson \& Franchimont (1981). The doses of reference standard and the ovarian-cell culture media were tested in 3-5 replicate wells. After the basal incubation, the media were removed and the pituitary cells were stimulated with LHRH $\left(10^{-8} \mathrm{M}\right)$ for $6 \mathrm{~h}$ in the presence of the same amount of ovarian-cell culture medium or the standard material which was used during the incubation in the basal condition. Serum-free DMEM was used to adjust the incubation volume to $1 \mathrm{ml}$.

This bioassay was validated for the inhibin present in rat ovarian-cell culture medium by the method described by Croze \& Franchimont (1984). The activity of inhibin present in the culture medium from rat ovarian cells was measured on one occasion in basal secretion and for all the experiments in the 6-h LHRH-induced secretion of FSH. The amount of inhibin present in the ovarian-cell culture medium was estimated from the regression line obtained for the reference standard and was considered detectable when the secretion of FSH in the absence of the inhibin standard was significantly reduced (Student's $t$ test, $P<0.05$ ). The limit of detection of the inhibin assay (broken line in the Text-figures) was the amount (U) of inhibin determined in the absence of the reference standard multiplied by the factor used to calculate the daily production +2 s.d.

\section{Culture of ovarian cells}

Wistar female rats, 21 days of age, were injected subcutaneously with PMSG (10 i.u./0.2 ml: Gestyl, N.V. Organon, Oss, The Netherlands) at $09: 00 \mathrm{~h}$ to stimulate the growth of ovarian cells (Suzuki \& Tamaoki, 1979). At $73 \mathrm{~h}$ after injection, the rats were decapitated, the ovaries collected and kept in Ham's F10 medium supplemented with L-glutamine ( $2 \mathrm{mM})$, penicillin $(100 \mathrm{U} / \mathrm{ml})$ and streptomycin $(100 \mu \mathrm{g} / \mathrm{ml})$ (Medium F10+ : Flow Laboratories, Irvine, U.K.). Adipose tissue and the bursa ovarica were dissected away and the ovaries were rinsed to remove fat droplets. The ovaries were punctured with a needle and treated according to the method of Campbell (1979) with EGTA (Sigma Chemical Co., St Louis, MO, U.S.A.) and hypertonic sucrose solutions to disrupt gap junctions and improve cell viability. After EGTA treatment, the ovaries were rinsed 3 times with Medium $\mathrm{F} 10+$.

Ovarian cells were obtained by a modification of the method of Hillier et al. (1977). The ovaries were pressed through stainless-steel grids (60 mesh: Falcon, Oxnard, CA, U.S.A.) with a spatula and the cells were recovered by agitating the grids in Medium F10 + . The cellular suspension was passed through a $100 \mu \mathrm{m}$ cell filter (Linker, Kassel, West Germany). The volume was measured and cellular concentration determined with a haemocytometer. Usually, $4.28 \times 10^{6} \pm 0.38$ cells/ovary (mean \pm s.d., $n=8$ ) were obtained using this method. Generally, $2 \times 10^{6}$ cells per dish $(60 \times 15$ $\mathrm{mm}$, Falcon) were incubated with $2 \mathrm{ml}$ Medium F10 + supplemented with $10 \%$ fetal calf serum $(\mathrm{F} 10+10 \% \mathrm{FCS})$ and kept at $37^{\circ} \mathrm{C}$ in an incubator with a gas phase of $95 \%$ air and $5 \% \mathrm{CO}_{2}$ saturated with water. The medium was changed every $24 \mathrm{~h}$ and stored at $-20^{\circ} \mathrm{C}$ until assayed for inhibin activity and steroids.

The inhibin activity was estimated from a pool of several dishes within an experimental group since in a preliminary experiment using 22 different groups, a coefficient of correlation of 0.90 was calculated between the average inhibin activity estimated from the individual $(y)$ dishes and from the pool $(x)$ of equal volume from those dishes $(y=0.6+1 \cdot 0 x)$.

Experiment 1. The effect of various percentages of FCS on inhibin and progestagen secretion was studied. The cells $\left(2 \times 10^{6}\right)$ were incubated with $2 \mathrm{ml} \mathrm{Medium} \mathrm{F10+10 \%} \mathrm{FCS} \mathrm{during} \mathrm{the} \mathrm{first}$ $24 \mathrm{~h}$, because in a preliminary experiment the serum was found to be necessary for the cells to adhere to the culture dish, as judged by the smaller concentration of cellular protein $(\mu \mathrm{g} / \mathrm{dish}, n=5)$ attached in the absence of serum $(97 \pm 11$, mean \pm s.d.) than in its presence $(385 \pm 11)$. After the first $24 \mathrm{~h}$ of culture, medium was removed, the cells were rinsed with $3 \times 1 \mathrm{ml}$ Medium F10 and incubated with $2 \mathrm{ml} \mathrm{Medium} \mathrm{F10+} \mathrm{with} 0,2 \cdot 5,5 \cdot 0,7 \cdot 5,10 \cdot 0$ or $12 \cdot 5 \%$ FCS. Before the adsorption by charcoal : dextran, the percentage of FCS in the various ovarian-cell culture media was adjusted 
to $12.5 \%$ to have the same protective effect against adsorption of inhibin by the charcoal : dextran treatment (Croze \& Franchimont, 1984).

Experiment 2. Initially, $0 \cdot 5,1 \cdot 0,1 \cdot 5,2 \cdot 0,3 \cdot 0$ or $4 \cdot 0 \times 10^{6}$ cells were added to each dish to determine the optimal number of cells needed for the production of inhibin when $10 \%$ FCS was included in the culture medium.

Experiment 3. Four different FCS preparations and 4 sera from newborn calves were checked for their effect on the production of inhibin and progestagens by rat ovarian cells. In this experiment the ovarian cells were incubated with Medium F10+ plus $10 \% \mathrm{FCS}$ during the first day of culture. They were then rinsed with $3 \times 1 \mathrm{ml}$ Medium $\mathrm{F} 10+$ and incubated with $10 \%$ of one of the four different batches of FCS or newborn calf serum for the next 4 days of culture.

Experiment 4. Four different batches of FCS were unadsorbed or absorbed with charcoal : dex$\operatorname{tran}(1 \cdot 0: 0 \cdot 1 \%, \mathrm{w} / \mathrm{v})$ by the same method as used for the ovarian-cell culture medium before addition to Medium $\mathrm{F} 10+$ to examine their influence on inhibin and steroid production. In each dish $2 \times 10^{6}$ cells were cultured in $2 \mathrm{ml}$ Medium $\mathrm{F} 10+$ which contained $10 \%$ of the appropriate serum. In this experiment, the protein and desoxyribonucleic acid (DNA) content of the cells were measured as an index of cellular growth.

\section{Determination of cellular protein and desoxyribonucleic acid}

At the end of the incubation period the culture media were removed and the dishes maintained on ice. The cells were washed with $2 \times 1 \mathrm{ml}$ chilled phosphate-buffered saline (PBS; Flow Laboratories) and detached by scraping with a rubber policeman into $3 \times 1 \mathrm{ml}$ chilled PBS. The cellular protein was determined by the method of Lowry, Rosebrough, Farr \& Randall (1951) and the DNA content by the fluorometric method described by Puzas \& Goodman (1978). The cell solutions were thawed and maintained in an ice bath from the time of lysis of the cells by sonication to the end of the DNA extraction procedure. Fraction V of BSA and the DNA derived from calf thymus (type II, sodium salt, highly polymerized: Sigma) were used as standards for protein and DNA determinations, respectively.

\section{Radioimmunoassays}

The concentrations of FSH in the culture media from the pituitary cells were measured by an heterologous double-antibody radioimmunoassay as described by Croze \& Franchimont (1984) using a first antibody raised against ovine FSH (Derivaux, Ectors, Hendrick \& Franchimont, 1974) or the antibody raised against rat FSH (anti rFSH-S-11) supplied by the NIAMDD. The rat FSH used as standard, rFSH-RP1, and tracer, rFSH-I-5, was from the NIAMDD.

The concentration of FSH, and LH in the FCS and newborn calf serum were measured using rat FSH and LH tracers (rLH-I-5) and antisera (anti rLH-S-7), supplied by the NIAMDD. Purified bovine gonadotrophins provided by Bioproducts, Peptide Department (UCB, Brussels, Belgium) were used as standards. The bovine FSH had a potency 60 times that of NIH-FSH-B1 (SteelmanPohley assay) with LH contamination $<3 \%$ (RIA) or $0.45 \%$ (RRA). The bovine LH had a biological activity of $2.3 \mathrm{i} . \mathrm{u} . / \mathrm{mg}$ (Parlow assay) with an FSH contamination of $<0.05 \%$ (by bioassay with NIH-FSH-S9 as standard). The cross-reactions of bovine FSH and LH were complete in their respective assays. The rat FSH and LH standard curves were steeper than the bovine gonadotrophin standard curves and therefore not parallel. The sensitivity was $0.5 \mathrm{ng} \mathrm{FSH} /$ tube and $0.2 \mathrm{ng} \mathrm{LH} /$ tube with an intra-assay coefficient of variation of $10.4 \%$ and $7.5 \%$ respectively.

The concentrations of progestagens in the media from cultured rat ovarian cells were determined without extraction. The concentration of progestagens in the FCS unadsorbed or adsorbed with charcoal : dextran and newborn calf serum was measured after extraction with $3 \mathrm{ml}$ 
ethyl acetate. The extraction procedure removed $84 \cdot 8 \pm 5 \cdot 5 \%$ (mean \pm s.d., $n=10)$ of the labelled progesterone. The antiserum P04/11 Tg (kindly supplied by Professor U. Rosa) was raised against progesterone $11 \alpha$-hemisuccinate-bovine thyroglobulin in rabbit and used at a final dilution of $1: 5000$. The percentage cross-reaction of this antiserum in comparison to progesterone $(100 \%)$ was $0.3 \%$ for $17 \alpha$-hydroxyprogesterone, $0.05 \%$ for pregnenolone and $<0.001 \%$ for $20 \alpha$-hydroxy-4pregnen-3-one, corticosterone, cortisol, $5 \alpha$-dihydrotestosterone, 4-androstene-3,17-dione, testosterone and oestradiol-17 $\beta$.

The concentrations of androgens in the media from cultured ovarian cells and androgens and oestrogens in sera were measured using modified versions of the radioimmunoassays described by Croze \& Etches (1980) and Etches, Croze \& Duke (1981) respectively. The steroids were extracted with $3 \mathrm{ml}$ ethyl acetate (analytical grade: Merck, Darmstadt, West Germany) before assay. This procedure extracted $87 \cdot 7 \pm 3 \cdot 1$ and $91 \cdot 2 \pm 3 \cdot 4 \%$ (mean \pm s.d., $n=10$ ) of the labelled testosterone and oestradiol-17 $\beta$. The concentrations of steroids were corrected for extraction losses. Tritiated steroids were purchased from New England Nuclear (Boston, MA, U.S.A.).

The standard curves for the steroid assays ranged from 6.25 to $3200 \mathrm{pg}$ progesterone/tube and $3 \cdot 125$ to $1600 \mathrm{pg}$ testosterone or oestradiol-17 $\beta /$ tube. The sensitivities of the assays were $6 \cdot 3 \pm 2 \cdot 8$ pg progesterone/tube (mean \pm s.d., $n=18), 2 \cdot 8 \pm 1 \cdot 1 \mathrm{pg}$ testosterone/tube $(n=15)$ and $4.2 \pm 1.9$ pg oestradiol- $17 \beta /$ tube $(n=26)$. The within- and between-assay coefficients of variation for the 3 assays were $9 \cdot 8$ and $19.3 \%$ respectively. The regression equation calculated between known amounts of unlabelled steroid added to pooled samples $(x)$ and the concentration measured per tube $(y)$ gave slopes not different from $1(P>0.05)$ for the 3 steroid radioimmunoassays.

\section{Statistical analysis}

An analysis of variance was used when several experimental groups were compared. When the variance of these groups was heterogeneous (Bartlett's test), the data were transformed to logarithms before the analysis of variance (Steel \& Torrie, 1960). Values for experimental groups that were significantly different at $P<0.05$ were identified by Scheffés multiple comparison test (Pollard, 1977).

\section{Results}

\section{Influence of serum on inhibin and progestagen production and cellular protein}

The inhibin contained in the ovarian-cell culture media was measured in the basal and LHRHstimulated conditions (Text-fig. 1a, b).

The inhibin activity in the culture medium from rat ovarian cells incubated without serum was only detectable during Day 2 when determined in basal conditions. A significant amount of inhibin could be measured in the culture medium from cells incubated with $2 \cdot 5 \%$ FCS from Days 2-5 in basal conditions while after treatment with LHRH the amount of inhibin was only detectable on Days 2 and 3. The inhibin content in culture medium from ovarian cells cultured with percentages of serum from 5.0 to $12.5 \%$ was always detectable in both assay conditions. The daily inhibin secretion was proportional to the percentage of FCS included in the culture medium $(r>0.89$, $n=6, P<0.05$ ) and the concentrations of 10 and $12.5 \%$ FCS were most effective for maintaining inhibin secretion. A coefficient of correlation of $0.94(n=24, P<0.001)$ was calculated between the daily inhibin secretion measured in the basal and the LHRH conditions but the relative activity was smaller when LHRH was added.

The secretion of progestagens (Text-fig. 1c) diminished with the duration of the culture period regardless of the percentages of serum present in the culture medium. Coefficients of correlation between 0.70 and $0.95(P<0.001)$ were calculated between the daily secretion of progestagens and the percentage of FCS in the medium. 


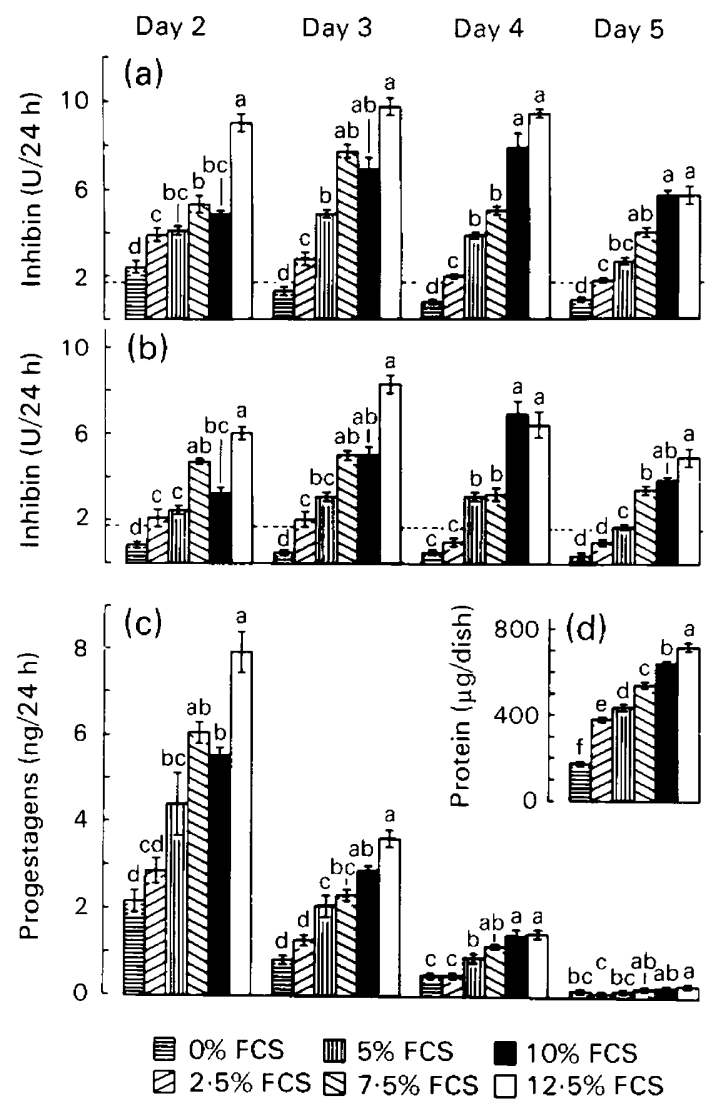

Text-fig. 1. Daily production (mean \pm s.e.m., $n=3$ for each value in (a) and (b), and 5 in (c) and (d)) of inhibin determined in basal conditions (a) and in the presence of LHRH (b) and of progestagens (c) and cellular protein content (d) at the end of the experimental period from rat ovarian cells cultured with Medium F10 + without FCS or with $2 \cdot 5,5 \cdot 0,7 \cdot 5,10 \cdot 0$ or $12 \cdot 5 \% \mathrm{FCS}$. Means within each day of culture that have the same letter are not statistically different, $P>$ 0.05 . The broken line indicates the limit of detection of the inhibin assay.

The cellular protein content determined after the last day of culture (Day 5) was proportional ( $r=0.98, P<0.001$ ) to the percentage of FCS to which the ovarian cells were exposed during the experimental period (Text-fig. 1d).

\section{Optimal number of cells for inhibin production}

The daily production of inhibin determined in the presence of LHRH and progestagen secretion from $0.5,1 \cdot 0,1.5,2 \cdot 0,3.0$ and $4.0 \times 10^{6}$ cells/dish initially incubated during a 3 -day incubation is summarized in Text-fig. 2.

During the first $24 \mathrm{~h}$ of incubation, the production of inhibin for a cellular concentration between 1.5 and $4.0 \times 10^{6}$ was not different, but $1 \times 10^{6}$ cells produced significantly less inhibin than did $2 \times 10^{6}$ cells and $0.5 \times 10^{6}$ cells produced an amount of inhibin only slightly greater than the limit of detection of the bioassay. During Day $2,4.0 \times 10^{6}$ cells produced a significantly greater concentration of inhibin than did 1.5, 2.0 and $3.0 \times 10^{6}$ cells whose production was not different. At that time, dishes inoculated with 0.5 and $1.0 \times 10^{6}$ cells had no detectable production of inhibin. 


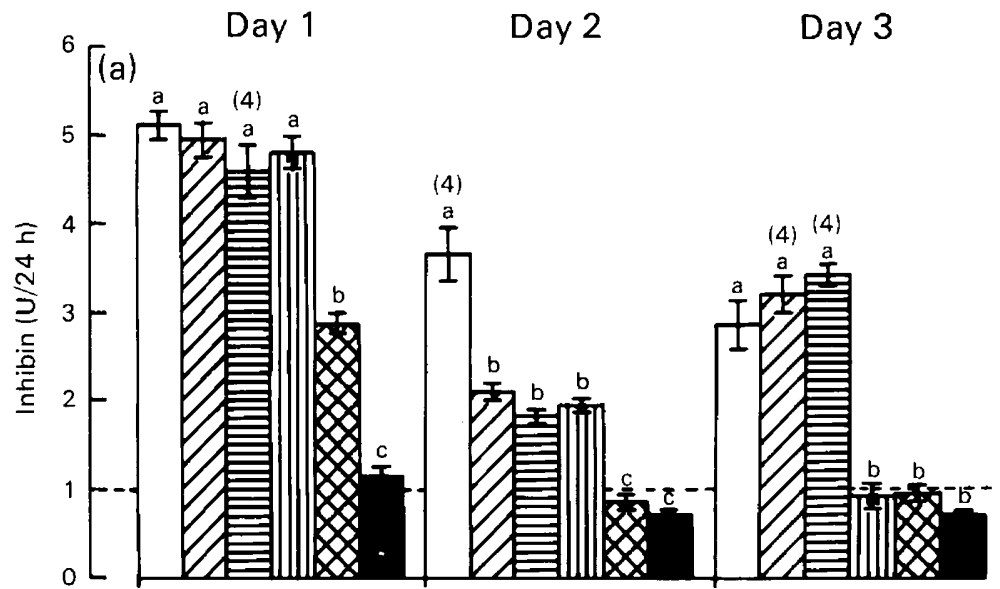

Cells/dish $\times 10^{6}$
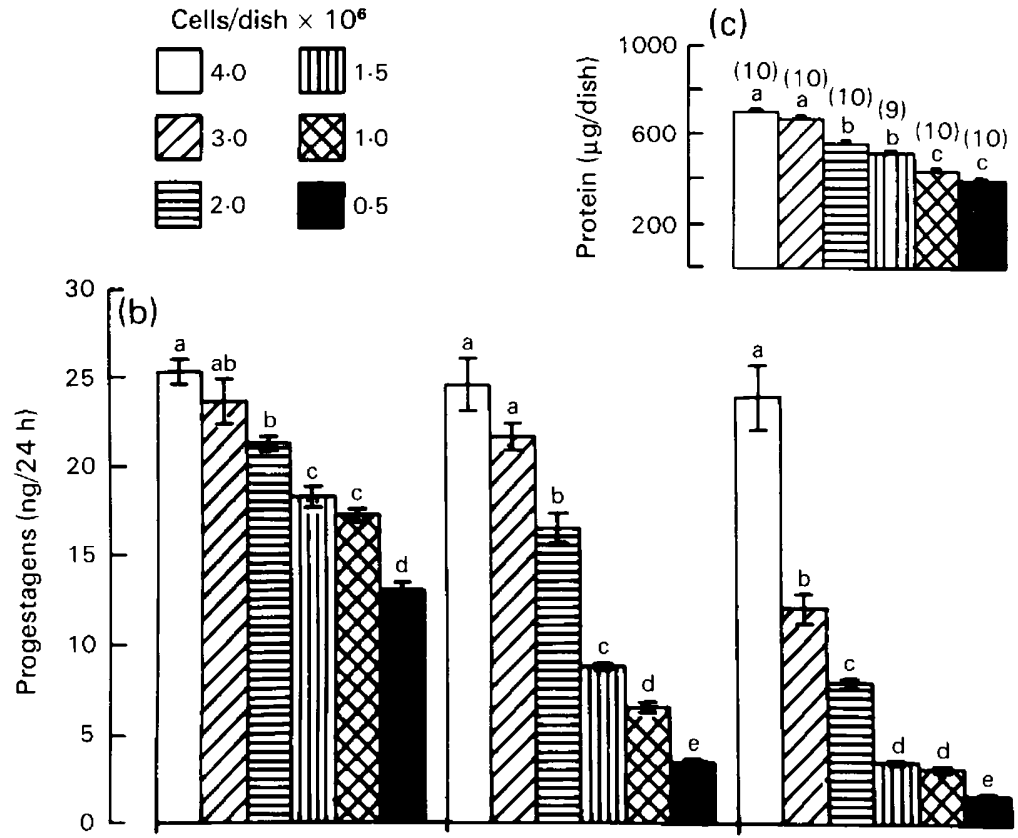

Text-fig. 2. Daily production (mean \pm s.e.m., $n=5$ except as indicated in parentheses) of inhibin (a) and progestagens (b) and cellular protein content (c) at the end of the experimental period from $0 \cdot 5,1 \cdot 0,1 \cdot 5,2 \cdot 0,3 \cdot 0$ and $4 \cdot 0 \times 10^{6}$ cells per dish initially added and incubated with Medium $\mathrm{F} 10+$ plus $10 \%$ FCS. Means within each day of culture that have the same letter are not different, $P>0.05$. The broken line indicates the limit of detection of the inhibin assay.

During Day 3, the inhibin production of $2 \cdot 0,3 \cdot 0$ and $4 \cdot 0 \times 10^{6}$ cells was similar while the secretion of $0.5,1.0$ and $1.5 \times 10^{6}$ cells was not significant.

The secretion of progestagens from the dishes incubated with $4.0 \times 10^{6}$ cells was sustained while, in the other groups, progesterone secretion diminished with time of incubation. In contrast to inhibin production, the daily secretion of progestagens during the 3 days of culture was proportional to the number of cells initially added with a coefficient of correlation $>0.95(P<$ $0.001)$. 
The cellular protein content measured after the 3-day culture period for $0 \cdot 5,1 \cdot 0,1 \cdot 5,2 \cdot 0,3 \cdot 0$ and $4.0 \times 10^{6}$ cells/dish was proportional to the number of cells initially added $(r=0.94, P<0.001)$.

The effect of fetal calf serum and newborn calf serum on the production of inhibin and progestagens

The concentrations of progestagens, androgens, oestrogens, FSH and $\mathrm{LH}$ were measured in the FCS and newborn calf serum (Table 1). The concentrations of progestagens were similar in both types of sera. The concentrations of androgens and oestrogens were significantly greater in FCS. The concentration of FSH was significantly greater in the newborn calf serum, while there was no difference in $\mathrm{LH}$ concentration.

Table 1. The concentrations ( $\mathrm{ng} / \mathrm{ml}$ ) of progestagens, androgens, oestrogens, FSH and LH in the fetal calf serum (FCS) and the newborn calf serum

\begin{tabular}{lcc}
\hline & FCS & $\begin{array}{c}\text { Newborn calf } \\
\text { serum }\end{array}$ \\
\hline Progestagens & $0.17 \pm 0.04(4)$ & $0.24 \pm 0.21(4)$ \\
Androgens & $* 0.09 \pm 0.01(4)$ & $0.05 \pm 0.02(4)$ \\
Oestrogens & $*_{0.21} \pm 0.02(4)$ & $0.04 \pm 0.01(4)$ \\
FSH & $* 30 \pm 12(4)$ & $466 \pm 25(4)$ \\
LH & $1.41 \pm 0.33(4)$ & $1.60 \pm 0.22(4)$ \\
\hline
\end{tabular}

Values are mean \pm s.d. for the number of observations in parentheses.

${ }^{*} P<0.05$ compared with value for newborn calf serum.

No significant difference in inhibin production estimated in the presence of LHRH was found between cells incubated with the 4 different FCS batches, whereas daily non-systematic variation in inhibin production was observed with cells incubated with the 4 batches of newborn calf serum. The daily mean production of inhibin by the ovarian cells incubated with FCS or newborn calf serum was not statistically different during Day 2 but was significantly greater for cells exposed to FCS on Days 3-5 (Table 2).

Table 2. Daily production of inhibin and progestagens and cellular protein content at the end of the experimental period from rat ovarian cells incubated with Medium $\mathrm{F} 10+$ with $10 \% \mathrm{FCS}$ or newborn calf serum (NBCS)

\begin{tabular}{ccccccccc}
\hline & \multicolumn{2}{c}{ Inhibin $(\mathrm{U} / 24 \mathrm{~h})$} & & \multicolumn{2}{c}{ Progestagens $(\mathrm{ng} / 24 \mathrm{~h})$} & & \multicolumn{2}{c}{ Protein $(\mu \mathrm{g} / \mathrm{dish})$} \\
\cline { 2 - 3 } $\begin{array}{c}\text { Day of } \\
\text { culture }\end{array}$ & FCS & NBCS & & FCS & NBCS & & FCS & NBCS \\
\hline 2 & $10.0 \pm 0.4(16)$ & $9.8 \pm 0.5(16)$ & & $* 27.67 \pm 1.29(16)$ & $44.62 \pm 2.92(16)$ & & \\
3 & $* 7.9 \pm 0.5(14)$ & $6.4 \pm 0.3(15)$ & & $* 22.05 \pm 0.82(16)$ & $27.33 \pm 1.81(16)$ & & \\
4 & $* 9.5 \pm 0.5(16)$ & $7.1 \pm 0.4(13)$ & & $* 6.35 \pm 0.52(14)$ & $19.38 \pm 0.27(16)$ & & \\
5 & $* 7.7 \pm 0.2(14)$ & $4.7 \pm 0.4(16)$ & & $* 0.82 \pm 0.10(13)$ & $3.22 \pm 0.43(15)$ & $* 613 \pm 54(14)$ & $513 \pm 70(16)$ \\
\hline
\end{tabular}

Values are mean \pm s.e.m. for the number of observations in parentheses.

${ }^{*} P<0.05$ compared with value for NBCS.

As with inhibin production, there was daily non-systematic variation in progestagen secretion by cells incubated with newborn calf serum. Progestagen secretion was greater for ovarian cells cultured with newborn calf serum than with FCS during the experimental period (Table 2). 


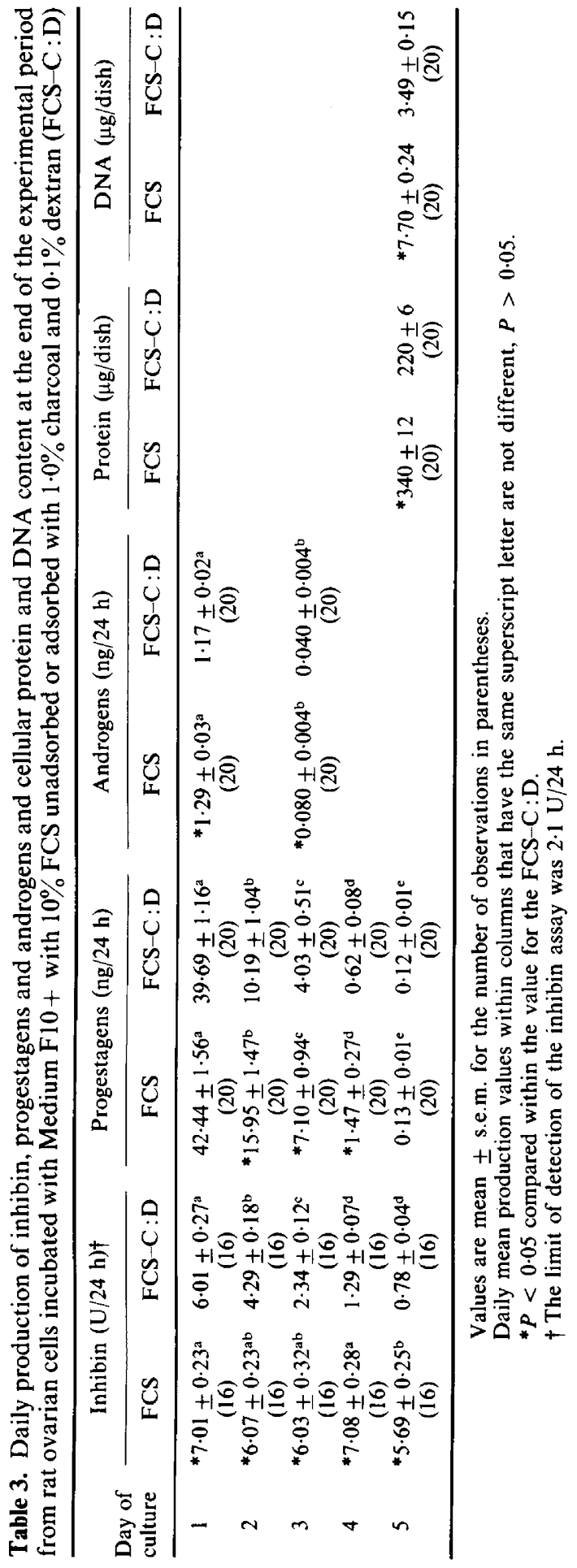


Cellular protein content measured from ovarian cells exposed to the FCS after the 5th day of culture was significantly greater than the protein content from the cells incubated with the newborn calf sera (Table 2).

Effect of adsorption of fetal calf serum with charcoal : dextran on inhibin and steroid production and cellular protein and DNA content

Four different preparations of FCS unadsorbed or adsorbed with $1.0 \%$ charcoal and $0.1 \%$ dextran were tested for their effect on the secretion of inhibin, progestagens and androgens.

The unadsorbed sera had an average progestagen concentration of $0.31 \pm 0.08 \mathrm{ng} / \mathrm{ml}$ (mean \pm s.d., $n=4$ ). After charcoal : dextran adsorption, the mean concentration of progestagens was not different from the concentrations of the sera when unadsorbed $(0.20 \pm 0.06 \mathrm{ng} / \mathrm{ml}, n=4, P>$ 0.05 ). The mean concentration of androgens in unadsorbed sera was $0.16 \pm 0.05 \mathrm{ng} / \mathrm{ml}$ (mean \pm s.d., $n=4)$ and this decreased to an undetectable amount $(<0.007 \mathrm{ng} / \mathrm{ml})$ after charcoal :dextran treatment. The concentration of oestrogens in the 4 serum batches ranged from 0.16 to $1.62 \mathrm{ng} / \mathrm{ml}$ and decreased to $0.022 \pm 0.016 \mathrm{ng} / \mathrm{ml}$ after treatment.

A study on the effect of charcoal :dextran treatment on gonadotrophin concentration showed that adsorption of sera with charcoal:dextran did not significantly alter the amount of immunoreactive FSH present in sera $(t=2 \cdot 02, n=12, P>0 \cdot 05)$, but immunoreactive LH was significantly diminished by approximately $40 \%(t=5.37, n=12, P<0.001)$.

The daily mean production of inhibin assayed in the presence of LHRH by cells exposed to unadsorbed sera was maintained although the production during Day 5 was significantly lower than the production during Days 1 and 4 (Table 3). In contrast, cells incubated with adsorbed sera were unable to sustain their inhibin production. At Day 1, the production of inhibin $(y)$ in the presence of adsorbed sera was already lower than the production observed in the presence of unadsorbed sera and it gradually decreased with the day of incubation $(x)$ to reach undetectable amounts by Days 4 and $5(\ln y=2.39-0.53, \ln x, r=0.97, n=80, P<0.001)$.

The production of progestagens by ovarian cells exposed to unadsorbed and charcoal : dextranabsorbed sera progressively decreased with the time of incubation (Table 3). During the first $24 \mathrm{~h}$ of culture and Day 5 , the production of progestagens was not significantly different for the cells incubated with unadsorbed or adsorbed sera. However, during Days $2-4$, the production by cells exposed to unadsorbed sera was always greater than the production by cells incubated with adsorbed sera.

During Days 1-3, production of androgens from cells incubated with unadsorbed sera was always greater than that from cells exposed to sera adsorbed with charcoal: dextran (Table 3).

At the end of the 5-day incubation, the cellular protein and the DNA content for the cells incubated with unadsorbed and charcoal: dextran adsorbed sera were significantly lower for the cells cultured with the charcoal: dextran-adsorbed sera (Table 3).

Cellular protein and DNA content were measured daily for cells incubated in Medium F10+ with one of the FCS batches (Table 4). The cellular protein content increased during the first 4 days of culture and stabilized by Day 5. The highest content of DNA was measured after the 1st day of incubation; it decreased during the 2 nd day and then stabilized.

\section{Discussion}

The ovarian cells from immature rats injected with PMSG secrete inhibin for several days and decreasing amounts of progestagen and androgens. The optimal number of cells to plate to measure detectable amounts of inhibin daily in the culture medium is $2 \times 10^{6}$ cells $/ \mathrm{dish}$. The population of cells harvested by this modified method of Hillier et al. (1977) is probably heterogeneous, consisting of granulosa cells as well as theca and interstitial cells because no thecal layer remains after the collection and about 4 times more cells were obtained than in the original procedure. This was biochemically supported by the significant secretion of androgens as measured here and reported by Croze \& Franchimont (1984). Downloaded from Bioscientifica.com at 04/26/2023 08:58:10AM 
Table 4. Cellular protein and DNA content (mean \pm s.e.m., $n=5$ ) measured daily during the 5 days of culture for cells incubated with Medium F10+ plus $10 \%$ of one of the batches of FCS

\begin{tabular}{crc}
\hline Day of culture & Protein $(\mu \mathrm{g} / \mathrm{dish})$ & DNA $(\mu \mathrm{g} / \mathrm{dish})$ \\
\hline 1 & $96 \cdot 4 \pm 10 \cdot 7^{\mathrm{c}}$ & $8 \cdot 52 \pm 0.99^{\mathrm{a}}$ \\
2 & $139 \cdot 1 \pm 14 \cdot 6^{\mathrm{b}}$ & $6.07 \pm 0.73^{\mathrm{b}}$ \\
3 & $163 \cdot 1 \pm 17 \cdot 3^{\mathrm{b}}$ & $5 \cdot 88 \pm 0 \cdot 15^{\mathrm{b}}$ \\
4 & $280 \cdot 3 \pm 25 \cdot 6^{\mathrm{a}}$ & $7.01 \pm 0.29^{\mathrm{a}, \mathrm{b}}$ \\
5 & $265 \cdot 1 \pm 24 \cdot 0^{\mathrm{a}}$ & $6 \cdot 73 \pm 0.49^{\mathrm{b}}$ \\
\hline
\end{tabular}

Means with the same superscript letter are not significantly different, $P>0.05$.

The influence of ovarian cell heterogeneity on the secretion of inhibin in long-term culture has not yet been investigated. It has been reported that during the first $24 \mathrm{~h}$ of culture the production of inhibin by bovine granulosa cells in association with bovine theca cells is intermediary (Henderson \& Franchimont, 1983). G. Verhoeven \& P. Franchimont (unpublished results) have observed a greater production of inhibin by Sertoli cells in the presence of peritubular cells. Steinberger, Seethalakshmi, Kessler \& Steinberger (1983) did not obtain an increase in inhibin secretion when Sertoli cells were co-cultured with peritubular cells, but the inhibition of the secretion of FSH in basal conditions by the culture medium from the Sertoli cells alone was already $60 \%$, and in these conditions a beneficial effect of the co-culture might not have been detected. A beneficial effect of the co-culture of the Sertoli cells with myoid cells on the production of androgen-binding protein has been reported by Tung \& Fritz (1980).

The inhibin production by bovine granulosa cells during the first day of culture is much higher than in our model but diminished markedly on the 2nd day (Henderson \& Franchimont, 1981). In contrast, with rat granulosa cells (Hermans et al., 1982) and the ovarian cells of the present model, inhibin production is maintained. This difference in the pattern of inhibin production could be due to a species difference or to a more advanced stage of maturity of the bovine cells. The bovine granulosa cells, which are obtained from the visible antral follicles of cyclic cows, have the intrinsic ability to luteinize and secrete increasing amounts of progesterone in vitro (Henderson \& Moon, 1979; Henderson \& Franchimont, 1981) while the secretion of progestagens by ovarian cells from immature rats injected with PMSG decreases with the duration of culture.

From the present study on the determination of the optimal culture conditions of rat ovarian cells to maintain inhibin production, we find that serum is an essential constituent of the culture medium and that the effect of serum is not only due to a protection of inhibin against charcoal:dextran adsorption (Croze \& Franchimont, 1984). It is known that serum provides specific cellular nutrients in a physiologically balanced manner (May \& Schomberg, 1981), enhances amino acid (Allen, Nilsen-Hamilton, Hamilton \& Gospodarowicz, 1979) and glucose (Allen, Nilsen-Hamilton \& Hamilton, 1981) uptake and can be mitogenic for ovarian cells (Johnson, Dawson, Turner \& Wyche, 1980; Orly et al., 1980). This positive effect of serum on inhibin production depends on the source of serum since serum from bovine fetuses was better able to maintain the production of inhibin than was that from newborn calves. This difference was probably not due to a harmful effect because ovarian cells cultured with newborn calf serum produced more progestagens than did cells incubated with FCS. The fact that the ovarian cells incubated with the sera having the higher concentration of FSH (newborn calves) produced lower amounts of inhibin does not seem to be in agreement with a simple direct physiological interaction between the two hormones and contrasts with the stimulatory effect of FSH on the secretion of inhibin by Sertoli cells (Le Gac \& de Kretser, 1982; Steinberger et al., 1983). Nevertheless, this is an observation of differential inhibin secretion in the presence of different concentrations of FSH. 
The ability of FCS to support inhibin production from rat ovarian cells seems to be linked to some extent to substances adsorbed by charcoal : dextran. However, it is unlikely that progestagens have a beneficial effect on inhibin production since treatment with charcoal : dextran failed to adsorb progestagens. Furthermore, a lower amount of inhibin was measured in the culture media from ovarian cells which secreted greater amounts of progestagens in the presence of newborn calf serum and it has also been reported that a high exogenous progesterone concentration decreases the production of inhibin by bovine granulosa cells (Henderson \& Franchimont, 1981). The possibility that the endogenous androgens and oestrogens present in the intact serum may be partly responsible for the maintenance of inhibin production cannot be excluded since both steroids were adsorbed by the charcoal : dextran treatment and ovarian cells incubated with FCS that contained more androgens than did the newborn calf sera secreted more inhibin. Finally, it has been demonstrated that bovine granulosa cells exposed to exogenous androgens secrete more inhibin (Henderson \& Franchimont, 1981, 1983). Epidermal and fibroblast growth factor, insulin and somatomedins which favour mitosis, protein synthesis of granulosa cells in vitro (Gospodarowicz \& Bialecki, 1979; Gospodarowicz, Vlodavsky, Savion \& Johnson, 1980; Savion \& Gospodarowicz, 1980; Gospodarowicz, Savion, Giguere \& Tauber, 1981) could be other charcoal:dextranadsorbable serum constituents involved in inhibin production.

There are also unadsorbable substances which appear to be involved in the production of inhibin since a detectable amount of inhibin was produced during the first 2 days of culture from cells incubated with Medium F10+ plus 10\% charcoal:dextran-adsorbed FCS. One of these elements could be serum lipoprotein which promotes the proliferation of granulosa cells (Savion, Lui, Laherty \& Gospodarowicz, 1981).

As in other studies (Channing et al., 1976; Orly et al., 1980; Hsueh et al.,1981), serum was ineffective in maintaining progesterone secretion. This inability of serum to sustain steroidogenesis could be related to some specific requirement for steroidogenic enzyme activity which is not provided by serum. Alternatively, various inhibitors of steroid synthesis may have been introduced since some authors have found that serum and growth factors may have a deleterious effect on steroidogenesis (Hsueh et al., 1976; Orly et al., 1980). Channing et al. (1976) suggested that the decrease in steroidogenic activity during cellular proliferation may be due to the greater demand for the synthesis of structural protein. Although we did observe an increase in protein synthesis, this was not associated with an increase in mitotic activity since cellular DNA content was stable during the 5 days of incubation and therefore the decrease in steroidogenesis does not appear to be linked to cell division in our study.

In conclusion, ovarian cells from immature rats injected with PMSG produced inhibin in a relatively constant amount for at least 5 days when $2 \times 10^{6}$ cells per dish $(60 \times 15 \mathrm{~mm})$ were cultured in the presence of FCS. This in-vitro system has the advantage that a great number of ovarian cells can be easily obtained at the same stage of maturity and it simulates the in-vivo situation since the population is heterogeneous. This model appears to be adequate for further studies on the hormonal regulation of inhibin production.

F.C. is a recipient of a Belgian-Canadian exchange fellowship. We thank Dr R. Gol-Winkler and $\mathrm{Mr} \mathrm{Ph}$. Legros for their help in measuring the DNA; Professor B. Hudson (Howard Florey Institute of Experimental Physiology and Medicine, University of Melbourne, Australia) for the OTLP $_{6}$ and RTFS; the NIAMDD for the rat pituitary gonadotrophin reagents; Dr F. Ectors (Faculté de Médecine Vétérinaire, Université de Liège, Belgium) for the ovine FSH antiserum; Professor U. Rosa (Laboratorio di Fisiologia Clinica, University of Pisa, Italy) for the progesterone antiserum; Dr R. J. Etches (Department of Animal Science, University of Guelph, Canada) for the testosterone and oestradiol antisera; Dr R. J. Etches and Mr M. McNamara for their help with the English of the manuscript; and Mrs S. Pregaldien and Mrs J. McDougald for typing the manuscript.

This research was supported by FRSM grant no. 3.4511.80. 


\section{References}

Allen, W.R., Nilsen-Hamilton, M., Hamilton, R.T. \& Gospodarowicz, D. (1979) Serum dependent regulation of $\alpha$-aminoisobutyric acid uptake in bovine granulosa cells. J. cell. Physiol. 98, 491-502.

Allen, W.R., Nilsen-Hamilton, M. \& Hamilton, R.T. (1981) Insulin and growth factors stimulate rapid post-translational changes in glucose transport in ovarian granulosa cells. J. cell. Physiol. 108, 15-24.

Campbell, K.L. (1979) Ovarian granulosa cells isolated with EDTA hypertonic sucrose : cellular integrity and function. Biol. Reprod. 21, 773-786.

Channing, C.P., Tsai, V. \& Sachs, D. (1976) Role of insulin, thyroxin and cortisol in luteinization of porcine granulosa cells grown in chemically defined media. Biol. Reprod. 15, 235-247.

Croze, F. \& Etches, R.J. (1980) The physiological significance of androgen-induced ovulation in the hen. $J$. Endocr. 84, 163-171.

Croze, F. \& Franchimont, P. (1984) Biological determination of inhibin in rat ovarian-cell culture medium. $J$ Reprod. Fert. 72, 237-248.

Derivaux, J., Ectors, F., Hendrick, J.C. \& Franchimont, P. (1974) Determination de la FSH plasmatique chez les bovins. Annls Endocr. 35, 614-621.

Eddie, L.W., Baker, H.W.G., Higginson, R.E. \& Hudson, B. (1979) A bioassay for inhibin using pituitary cell cultures. J. Endocr. 81, 49-60.

Erickson, G.F. \& Hsueh, A.J.W. (1978) Secretion of inhibin by rat granulosa cells in vitro. Endocrinology 103, 1960-1963.

Etches, R.J., Croze, F. \& Duke, C.E. (1981) Plasma concentrations of luteinizing hormone, progesterone, testosterone and estradiol in follicular and peripheral venous plasma during the ovulation cycle of the hen. In Recent Advances of Avian Endocrinology, pp. 89-98. Eds G. Pethes, P. Peczely \& P. Rudas. Pergamon Press, New York.

Gospodarowicz, D. \& Bialecki, H. (1979) Fibroblast and epidermal growth factors are mitogenic agents for cultured granulosa cells of rodent, porcine and human origin. Endocrinology 104, 757-764.

Gospodarowicz, D., Vlodavsky, I., Savion, N. \& Johnson, L.K. (1980) The effect of EGF on cell proliferation and gene expression. In Control Mechanisms in Animal Cells, pp. 61-83. Eds L. Jimenez de Asua, R. Levi-Montalcini, R. Shields \& S. Lacobelli. Raven Press, New York.

Gospodarowicz, D., Savion, N., Giguere, L. \& Tauber, J.P. (1981) Effects of fibroblast growth factor and basal lamina on the growth of normal diploid cells in serum-free medium. In Physiological Peptides and New Trends in Radioimmunology, pp. 127-148. Ed. Ch. A. Bizollon. Elsevier, North Holland/Biomedical Press, Amsterdam.

Henderson, K.M. \& Franchimont, P. (1981) Regulation of inhibin production by bovine ovarian cells in vitro. $J$. Reprod. Fert. 63, 431-442.

Henderson, K.M. \& Franchimont, P. (1983) Inhibin production by bovine ovarian tissues in vitro and its regulation by androgen. $J$. Reprod. Fert. 67, 291298 .
Henderson, K.M. \& Moon, Y.S. (1979) Luteinization of bovine granulosa cells and corpus luteum formation associated with loss of androgen-aromatizing ability. J. Reprod. Fert. 56, 89-97.

Hermans, W.P., van Leeuwen, E.C.M., Debets, M.H.M., Sanders, H.J. \& de Jong, F.H. (1982) Estimation of inhibin-like activity in spent medium from rat ovarian granulosa cells during long-term culture. Molec. cell. Endocr. 27, 277-290.

Hillier, S.G., Knazek, R.A. \& Ross, G.T. (1977) Androgenic stimulation of progesterone production by granulosa cells from preantral ovarian follicles: further in vitro studies using replicate cell culture. Endocrinology 100, 1539-1549.

Hsueh, A.J.W., Welsh, T.H. \& Jones, P.B.C. (1981) Inhibition of ovarian and testicular steroidogenesis by epidermal growth factor. Endocrinology 108, 20022004.

Johnson, C.C., Dawson, W.E., Turner, J.T. \& Wyche, J.H. (1980) Regulation of rat ovarian cell growth and steroid secretion. J. Cell Biol. 86, 483-489.

Le Gac, F. \& de Kretser, D.M. (1982) Inhibin production by Sertoli cell culture. Molec. cell. Endocr. 28, 487498.

Lowry, O.H., Rosebrough, N.J., Farr, A.L. \& Randall, R.J. (1951) Protein measurement with the folin phenol reagent. J. biol. Chem. 193, 265-275.

May, J.V. \& Schomberg, D.W. (1981) Granulosa cell differentiation in vitro: effect of insulin on growth and functional integrity. Biol. Reprod. 25, 421-431.

Orly, J., Sato, G. \& Erickson, G.F. (1980) Serum suppresses the expressions of hormonally induced functions in cultured granulosa. Cell 20, 817-827.

Pollard, J.H. (1977) A Handbook of Numerical Statistical Techniques. Cambridge University Press.

Puzas, J.E. \& Goodman, D.B.P. (1978) A rapid assay for cellular deoxyribonucleic acid. Analyt. Biochem. 86, $50-55$.

Savion, N. \& Gospodarowicz, D. (1980) Patterns of cellular peptide synthesis by cultured granulosa cells. Endocrinology 107, 1787-1807.

Savion, N., Lui, G.M., Laherty, R. \& Gospodarowicz, D. (1981) Factors controlling proliferation and progesterone production by bovine granulosa cells in serumfree medium. Endocrinology 109, 409-420.

Steel, R.G.D. \& Torrie, J.H. (1960) Principles and Procedures of Statistics. McGraw-Hill, New York.

Steinberger, A., Seethalakshmi, L., Kessler, M. \& Steinberger, E. (1983) Sertoli cell factor. In Role of Peptides and Proteins in Control of Reproduction, pp. 215-236. Eds S. M. McCann and D. S. Dhindsa. Elsevier Biomedical, Amsterdam.

Suzuki, K. \& Tamaoki, B.I. (1979) Enzymological studies of rat luteinized ovaries in relation to acute reduction of aromatizable androgen formation and stimulated production of progestins. Endocrinology 104, 13171323.

Tung, S. \& Fritz, I.B. (1980) Interaction of Sertoli cells with myoid cells in vitro. Biol. Reprod. 23, 207-217.

Received 13 October 1983 